\title{
Genetic overload of silver fir (Abies alba Mill.) from five populations from central Bosnia and Herzegovina
}

\author{
Dalibor Ballian \\ University of Sarajevo, Faculty of Forestry, Zagrebacka 20, 71000 Sarajevo, Bosnia and Herzegovina, \\ e-mail:balliandalibor9@gmail.com
}

\begin{abstract}
The research was conducted with a view to establishing physiological parameters of the silver fir (Abies alba Mill.) with regard to germination energy, absolute germination and genetic overload produced by silver fir populations. The intention was to identify significant variability within populations and subpopulations, or rather within the two combined, and to give recommendations on the usage and usability of seeds from specific populations. The results form a basis for establishing silver fir genetic overload within five fir populations of central Bosnia and Herzegovina.

The results of research on the characteristics such as absolute seed weight, germination energy and absolute germination are within a scope of previous studies.

The studied physiological characteristics of silver fir seeds in the central Bosnia area showed distinct individual and inter-population variability when compared to variability of the subpopulations analyzed.

The inclusion of non-physiological data (height, DBH, age and the presence of mistletoe) concerning sampled trees proved to be effective new quality of research. No correlation was found between DBH and seed physiological characteristics but increased tree height had a positive effect on seed quality in terms of absolute germination and growth, proportional to tree height. This in turn shows that seeds should be collected only from trees of above average height, because they are less genetically overloaded.

The characteristics of healthy but ungerminated seeds from less tall trees displayed lower parameter values, also indicating that seeds should be collected from taller than average trees only.

The presence of mistletoe had a very interesting effect of increasing rotten seeds percentage, and therefore reducing seed quality. Accordingly, seed collection should be limited to trees not affected by mistletoe, however further research on this aspect is required.
\end{abstract}

\section{KeY WORDS}

seeds, germination, ungerminated seeds, rotten seeds, empty seeds, populations 


\section{INTRODUCTION}

Silver fir (Abies alba Mill.) is Bosnia and Herzegovina's most important coniferous species from the perspective of both the environment and husbandry. In Bosnia and Herzegovina it is widespread along the Dinaric Alps in a few remote areas, of which some are fairly large (Fukarek 1970). According to the old forest inventory, tall forests with silver fir account for 562237 ha or about 50\% of all tall forests in Bosnia and Herzegovina (Matić et al. 1971). The total reserve mass of silver fir timber in forests is $69923000 \mathrm{~m}^{3}$ (1990 data) that is $23 \%$ of total tree mass in all tall forests which is equivalent to the share of silver fir in the timber industry. Unfortunately, the general state of health and well being of these forests is not good. Nothing like the same type of forest in Croatia, where the silver fir is slowly dwindling due to adverse effects of atmospheric and soil pollution (Tikvić et al. 1995), in Bosnia, the deterioration is due to poor forest management, which is undermining the stability of fir forests and causing increased occurrence of mistletoe (Viscum album var. abietis Beck.) (Uščuplić 1992). Mistletoe is a constant companion as mismanagement and unskilled felling of stands favour its spread followed by disintegration of many fir forests by allowing intrusion of aggressive beech into fir stands. Slight damage from atmospheric pollution was registered just before the war, and namely in 1991/1992, near the border with Croatia, in the Bosanska Krajina region and in small areas nearby heavy pollutant producers (thermal power plants, chemical industry, metallurgy, etc.), however, it was largely contained. Not like in Bosnia and Herzegovina, several studies on silver fir germination and absolute weight, as well as its physiological features, have been conducted in Europe (Gagov 1973; Lafférs 1970, 1979; Popnikola 1979). In Bosnia and Herzegovina, however, some planning was carried out along these lines, in particular by Čabrajić (1960) and Đikić et al. (1965).

The literature on seed germination provides extensive data, and especially those obtained by: Vanin (1960) who observed germination of silver fir seeds from $40 \%$ to $70 \%$, Gajić (1962) - from 14.6 to $49.0 \%$, Machaniček (1967) and Kantor (1967) - from 5 to 89\%, Čabrajić (1960) - from 31 to 40\%, and Gagov (1973) who found that the purplish form of seed indicated a germination level from $26 \%$ to $37 \%$, whereas the brownish form ranged from $18.3 \%$ to $54.9 \%$ and the pale yellow form - from $25.9 \%$ to
$50.1 \%$. Popnikola (1979) showed the values from $27 \%$ for the grey form to $46.2 \%$ for the intermediate form. Rohmeder (1960) stated that seed germination was $28.2 \%$. According to Gagov (1973), germination values ranged from $22.6 \%$ to $50.8 \%$, depending on seed origin. Đikić et al. (1965) claimed that the germination of seeds in Bosnia was $8-10 \%$ after mechanical processing. Finally, Gradi (1973) stated that after storing at temperature from $8^{\circ} \mathrm{C}$ to $10^{\circ} \mathrm{C}$ and humidity from $7 \%$ to $8 \%$ for three years, seed germination decreased to $10-15 \%$.

The present study was conducted with a view to establishing silver fir physiological parameters with regard to germination energy, absolute germination and genetic overload produced by silver fir populations. The intention was to identify significant variability within the populations and subpopulations or rather within the two combined, and to give recommendations on the usage and usability of seeds from specific populations. The results obtained form a basis for establishing the genetic overload of the silver fir within the five populations of central Bosnia and Herzegovina.

\section{MATERIAL AND METHODS}

\section{Selection and description of field sites}

Silver fir trees from central Bosnia were selected in the autumn when the seeds ripen, based on the full production of seeds in five populations (fig. 1):

1. Igman population consisting of:

a. Ravne subpopulation, limestone, altitude $1200 \mathrm{~m}$, northern exposure (Longitude 434' $16^{\prime \prime}$ - Latitude 18०16'29'”)

b. Lasički Stan subpopulation, limestone, altitude $1350 \mathrm{~m}$, southern exposure (Longitude $43^{\circ} 45^{\prime} 20^{\prime \prime}$ - Latitude $\left.18^{\circ} 16^{\prime} 48^{\prime \prime}\right)$

2. Fojnica population, consisting of:

a. Kozigrad subpopulation, phyllite, altitude $1050 \mathrm{~m}$, northern exposure (Longitude 4356'22" - Latitude 1754'16")

b. Bistrica subpopulation, phyllite, altitude $1320 \mathrm{~m}$, eastern exposure (Longitude 4354'50' - Latitude $\left.17^{\circ} 52^{\prime} 53^{\prime \prime}\right)$

3. Olovo population, consisting of:

a. Jelovac subpopulation, limestone, altitude $950 \mathrm{~m}$,

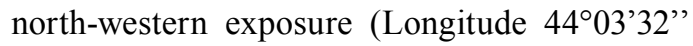
- Latitude 18³3'49'”) 
b. Mali Jelovac subpopulation, limestone, altitude $870 \mathrm{~m}$, northern exposure (Longitude $44^{\circ} 04^{\prime} 05^{\prime \prime}$, - Latitude $\left.18^{\circ} 36^{\prime} 41^{\prime \prime}\right)$

4. Kakanj population, consisting of:

a. Mehurić subpopulation, peridotite, sandstone, altitude $1000 \mathrm{~m}$, eastern exposure (Longitude 441'13" - Latitude $18^{\circ} 13^{\prime} 10^{\prime \prime}$ )

b. Podborovica subpopulation, Werfen, altitude 1100 $\mathrm{m}$, north-eastern exposure Longitude $44^{\circ} 12^{\prime} 50^{\prime}$ ' - Latitude $\left.18^{\circ} 15^{\prime} 09^{\prime \prime}\right)$

5. Crepoljsko population, consisting of:

a. Vukinjača subpopulation, limestone, altitude $1200 \mathrm{~m}$, western exposure (Longitude $43^{\circ} 58^{\prime} 48^{\prime \prime}$ - Latitude $\left.18^{\circ} 27^{\prime} 35^{\prime \prime}\right)$

b. Žorci subpopulation, limestone, altitude $1330 \mathrm{~m}$, south-western exposure (Longitude 435' $52^{\prime \prime}$ - Latitude 18³0'16’').

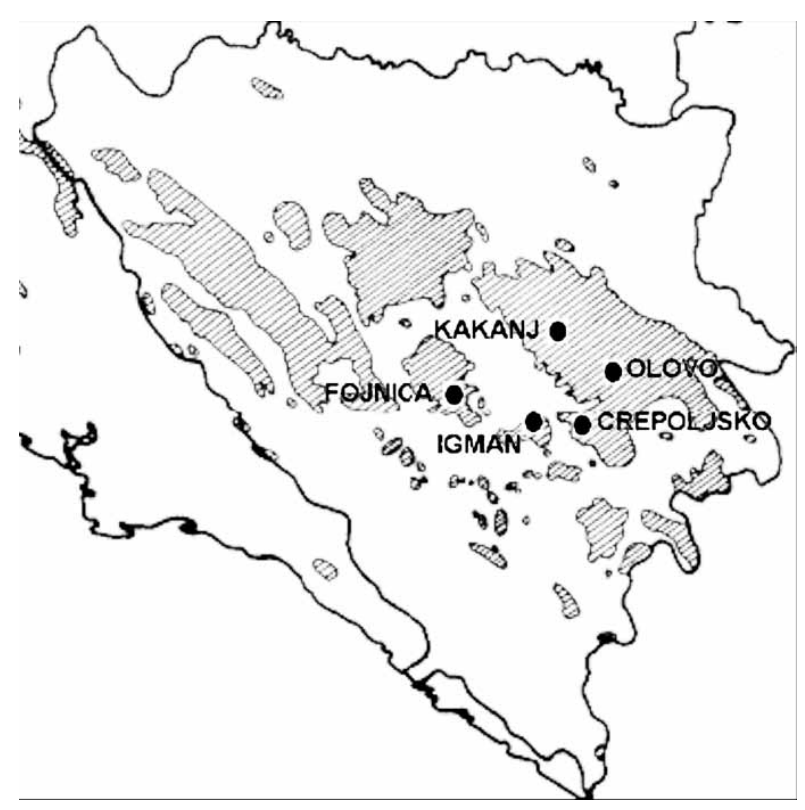

Fig. 1. Silver fir distribution in Bosnia and Herzegovina (Fukarek 1970) and localisation of the populations studied

All the populations were situated at least $30 \mathrm{~km}$ away from each other. Two groups were selected within every population, at different altitudes and on different exposures, and were examined separately to ensure that the population in question was represented most effectively. Each subpopulation was represented by 10 selected trees growing at least 50-100 m apart (a given population was represented by 20 trees). Dendrometric parameters of each tree were recorded, and the presence or absence of mistletoe was noted, and then the data obtained were used in correlation analysis. Care was also taken to ensure that the populations differed in their geological - or more accurately- pedelogical features and phytocenosis.

\section{Collection of samples and measuring of the characteristics studied}

There were collected 50 cones from each of the selected trees. Seed germination energy was studied along with absolute germination, and the numbers of: healthy and ungerminated seeds, rotten seeds and empty seeds were recorded. Seeds collected from the 50 cones were homogenized manually. For germination observations, seed wings were carefully removed in order not to damage the turpentine bubble which is essential for germination. The seed would not germinate if there were any turpentine touch to the embryo. Before beginning of the experiment we also investigated the pre-treatment of the seeds (wet-cold method), but the results suggested that there was no benefit to be obtained from this procedure.

The seeds were germinated in Petri dishes on filter paper at room temperature $\left(18-22^{\circ} \mathrm{C}\right)$ in normal daylight. Four repeat sessions $(4 \times 100$ seeds $)$ were conducted, with collections of seed portions for observations on germination energy (after 14 days) and absolute germination (after 35 days). The seeds were treated with Radomil fungicide during germination.

\section{Data processing}

The parameters analyzed were processed statistically using SPSS 15.0 package for Windows. The analyses included the following:

- individual intrapopulational variability of quantitative characteristics through descriptive indicators: average value, standard deviation, significance of differentiations and variability coefficient (sd/mean $\times 100)$,

- interpopulational variability through standard statistical indicators such as average, standard deviation, the minimum and maximum values and variability coefficient of the quantities,

- analysis of variance (ANOVA),

- canonical discriminant analysis,

- interdependencies through correlational indicators. 
The data on descriptive indicators were analyzed within the populations to establish whether there were any statistically significant differences between the analyzed populations. Correlation analysis was conducted to determine whether there were any co-dependencies between the characteristics - for this we introduced some of the dendrometrical parameters, such as the height and diameter of the trees from which the seeds were collected, as well as tree age and mistletoe damage.

\section{Results}

\section{Descriptive analysis}

As seed weights depend on the population which from the seeds originate, the data from this research (tab. 1) correspond with those on the weight of 1000 seeds obtained by Lafférs (1979) from $32.69 \mathrm{~g}$ to $76.42 \mathrm{~g}$ as well as Gagov (1973) and Popnikola (1979) - from $34 \mathrm{~g}$ to $82 \mathrm{~g}$.

Tab. 1. Descriptive indicators

\begin{tabular}{|l|c|c|c|c|c|}
\hline \multicolumn{1}{|c|}{ Traits } & $\mathrm{N}$ & Min. & Max. & Mean & $\begin{array}{c}\text { Std. } \\
\text { Deviation }\end{array}$ \\
\hline $\begin{array}{l}\text { Weight of } 1000 \\
\text { seeds (g) }\end{array}$ & 100 & 32.70 & 76.35 & 55.33 & 8.85 \\
\hline $\begin{array}{l}\text { Germination } \\
\text { energy (\%) }\end{array}$ & 100 & 2.00 & 30.50 & 5.32 & 5.67 \\
\hline $\begin{array}{l}\text { Absolute } \\
\text { germination (\%) }\end{array}$ & 100 & 4.00 & 60.25 & 24.82 & 12.68 \\
\hline $\begin{array}{l}\text { Healthy } \\
\text { ungerminated } \\
\text { seeds (\%) }\end{array}$ & 100 & 11.25 & 71.00 & 34.94 & 11.46 \\
\hline Rotten seeds (\%) & 100 & 0.00 & 16.00 & 3.65 & 3.16 \\
\hline Empty seeds (\%) & 100 & 15.00 & 71.00 & 36.72 & 10.11 \\
\hline
\end{tabular}

We were unable to make any comparisons for germination energy, as there are no data available in the literature. The results of this research range from $2 \%$ to $30.5 \%$ (tab. 1).

As far as absolute germination is concerned, we have access to some information from Čabrajić (1960), Vanin (1960), Gajić (1962), Đikić et al. (1965), Machaniček (1967), Gagov (1973) and Popnikola (1979) and others, with figures from 5 to $70 \%$, which is in agreement with the results presented in tab. 1. Even though they can play a large part in the assessment of the genetic overload of the silver fir, there is little information available on the number of healthy, ungerminated, rotten or empty seeds,. On this note, data is available from Gradečki-Poštenjak (2002), pointing out that poor quality ungerminated seeds account for between $29.20 \%$ and $73.77 \%$, without differentiating between ungerminated, rotten and empty seeds, but distinguishing between limestone and silicate bases.

\section{Analysis of variance at a subpopulations level}

We conclude from the results of the analysis of subpopulation variability (tab. 2) that 1000 - seed weights indicated no statistically significant differences, even though this was expected on the basis of unprocessed data.

Tab. 2. Analysis of variance at a subpopulations level

\begin{tabular}{|c|c|c|c|c|c|}
\hline & Traits & $\begin{array}{l}\text { Sum of } \\
\text { Squares }\end{array}$ & $\mathrm{df}$ & $\begin{array}{l}\text { Mean } \\
\text { Square }\end{array}$ & $\mathrm{F}$ \\
\hline \multirow{3}{*}{$\begin{array}{l}\text { Weight of } \\
1000 \text { seeds }\end{array}$} & Between Groups & 13.24 & 1 & 13.24 & 0.16 \\
\hline & Within Groups & $7,747.80$ & 98 & 79.05 & \\
\hline & Total & $7,761.04$ & 99 & & \\
\hline \multirow{3}{*}{$\begin{array}{l}\text { Germina- } \\
\text { tion en- } \\
\text { ergy }\end{array}$} & Between Groups & 1.38 & 1 & 1.38 & 0.04 \\
\hline & Within Groups & $3,191.90$ & 98 & 32.57 & \\
\hline & Total & $3,193.28$ & 99 & & \\
\hline \multirow{3}{*}{$\begin{array}{l}\text { Absolute } \\
\text { germina- } \\
\text { tion }\end{array}$} & Between Groups & 12.60 & 1 & 12.60 & 0.07 \\
\hline & Within Groups & $15,925.53$ & 98 & 162.50 & \\
\hline & Total & $15,938.13$ & 99 & & \\
\hline \multirow{3}{*}{$\begin{array}{l}\text { Healthy } \\
\text { unger- } \\
\text { minated } \\
\text { seeds }\end{array}$} & Between Groups & 6.25 & 1 & 6.25 & 0.04 \\
\hline & Within Groups & $13,016.89$ & 98 & 132.82 & \\
\hline & Total & $13,023.14$ & 99 & & \\
\hline \multirow{3}{*}{$\begin{array}{l}\text { Rotten } \\
\text { seeds }\end{array}$} & Between Groups & 16.20 & 1 & 16.20 & 1.63 \\
\hline & Within Groups & 972.63 & 98 & 9.92 & \\
\hline & Total & 988.83 & 99 & & \\
\hline \multirow{3}{*}{$\begin{array}{l}\text { Empty } \\
\text { seeds }\end{array}$} & Between Groups & 11.73 & 1 & 11.73 & 0.11 \\
\hline & Within Groups & $10,121.88$ & 98 & 103.28 & \\
\hline & Total & $10,133.61$ & 99 & & \\
\hline
\end{tabular}

Analysis of variance for germination energy at a subpopulation level showed no significant differences, but when the data analyzed were tested separately for each population by a paired difference test (tab. 2), $1 \%$ or $5 \%$ statistically significant differences were found (Ballian 2000). 
No statistically significant variations were observed in the case of absolute germination either using the method applied or pair testing - where only subpopulations within the selected populations were analyzed (Ballian 2000).

The analysis of ungerminated, rotten or empty and barren seeds yielded not statistically applicable data on the subpopulations analyzed (tab. 2).

\section{Analysis of variance at a population level}

Analysis of variance at a population level showed a striking interpopulational variability for all the characteristics studied, in the order of $1 \%$ or $5 \%$ (tab. 3). $F$ values obtained were different, and the greatest variations were observed at a interpopulational level in relation to absolute germination, reaching the value 17.95.

Tab. 3. Analysis of variance at a population level

\begin{tabular}{|c|c|c|c|c|c|}
\hline \multicolumn{2}{|c|}{ Traits } & $\begin{array}{l}\text { Sum of } \\
\text { Squares }\end{array}$ & df & $\begin{array}{l}\text { Mean } \\
\text { Square }\end{array}$ & $\mathrm{F}$ \\
\hline \multicolumn{2}{|l|}{1} & 2 & 3 & 4 & 5 \\
\hline \multirow{3}{*}{$\begin{array}{l}\text { Weight of } \\
1000 \text { seeds }\end{array}$} & $\begin{array}{l}\text { Between } \\
\text { Groups }\end{array}$ & 697.82 & 4 & 174.45 & $2.34^{*}$ \\
\hline & $\begin{array}{l}\text { Within } \\
\text { Groups }\end{array}$ & $7,063.22$ & 95 & 74.35 & \\
\hline & Total & $7,761.04$ & 99 & & \\
\hline \multirow{3}{*}{$\begin{array}{l}\text { Germination } \\
\text { energy }\end{array}$} & $\begin{array}{l}\text { Between } \\
\text { Groups }\end{array}$ & 831.99 & 4 & 207.99 & $8.36^{* *}$ \\
\hline & $\begin{array}{l}\text { Within } \\
\text { Groups }\end{array}$ & $2,361.29$ & 95 & 24.85 & \\
\hline & Total & $3,193.28$ & 99 & & \\
\hline \multirow{3}{*}{$\begin{array}{l}\text { Absolute } \\
\text { germination }\end{array}$} & $\begin{array}{l}\text { Between } \\
\text { Groups }\end{array}$ & $6,854.53$ & 4 & $1,713.63$ & $17.92^{* *}$ \\
\hline & $\begin{array}{l}\text { Within } \\
\text { Groups }\end{array}$ & $9,083.60$ & 95 & 95.61 & \\
\hline & Total & $15,938.13$ & 99 & & \\
\hline \multirow{3}{*}{$\begin{array}{l}\text { Healthy un- } \\
\text { germinated } \\
\text { seeds }\end{array}$} & $\begin{array}{l}\text { Between } \\
\text { Groups }\end{array}$ & $3,336.21$ & 4 & 834.05 & $8.18^{* *}$ \\
\hline & $\begin{array}{l}\text { Within } \\
\text { Groups }\end{array}$ & $9,686.92$ & 95 & 101.96 & \\
\hline & Total & $13,023.14$ & 99 & & \\
\hline \multirow{3}{*}{$\begin{array}{l}\text { Rotten } \\
\text { seeds }\end{array}$} & $\begin{array}{l}\text { Between } \\
\text { Groups }\end{array}$ & 149.24 & 4 & 37.31 & $4.22^{*}$ \\
\hline & $\begin{array}{l}\text { Within } \\
\text { Groups }\end{array}$ & 839.58 & 95 & 8.83 & \\
\hline & Total & 988.83 & 99 & & \\
\hline
\end{tabular}

\begin{tabular}{|l|l|c|c|c|c|}
\hline \multicolumn{2}{|c|}{1} & 2 & 3 & 4 & 5 \\
\hline \multirow{4}{*}{$\begin{array}{l}\text { Empty } \\
\text { seeds }\end{array}$} & $\begin{array}{l}\text { Between } \\
\text { Groups }\end{array}$ & $2,521.16$ & 4 & 630.29 & $7.86^{* *}$ \\
\cline { 2 - 6 } & $\begin{array}{l}\text { Within } \\
\text { Groups }\end{array}$ & $7,612.44$ & 95 & 80.13 & \\
\cline { 2 - 7 } & Total & $10,133.61$ & 99 & & \\
\hline
\end{tabular}

* significant at the 0.05 level.

** significant at the 0.01 level.

\section{Discriminant analysis}

The analysis revealed certain statistically significant variations or rather the absence of separation of the populations into groups. Eigenvalue was less than 1 in all functions (tab. 4).

Tab. 4. Discriminant analysis - Eigenvalues

\begin{tabular}{|c|c|c|c|c|}
\hline Function & Eigenvalue & $\begin{array}{c}\% \text { of } \\
\text { Variance }\end{array}$ & $\begin{array}{c}\text { Cumulative } \\
\%\end{array}$ & $\begin{array}{c}\text { Canonical } \\
\text { Correlation }\end{array}$ \\
\hline 1 & $0.866^{*}$ & 67.9 & 67.9 & 0.681 \\
\hline 2 & $0.249^{*}$ & 19.5 & 87.4 & 0.446 \\
\hline 3 & $0.135^{*}$ & 10.6 & 98.0 & 0.345 \\
\hline 4 & $0.025^{*}$ & 2.0 & 100.0 & 0.156 \\
\hline
\end{tabular}

${ }^{*}$ First 4 canonical discriminant functions were used in the analysis.

However, when we analyzed the grouping (centroids) of the populations as in fig. 2 , we observed low

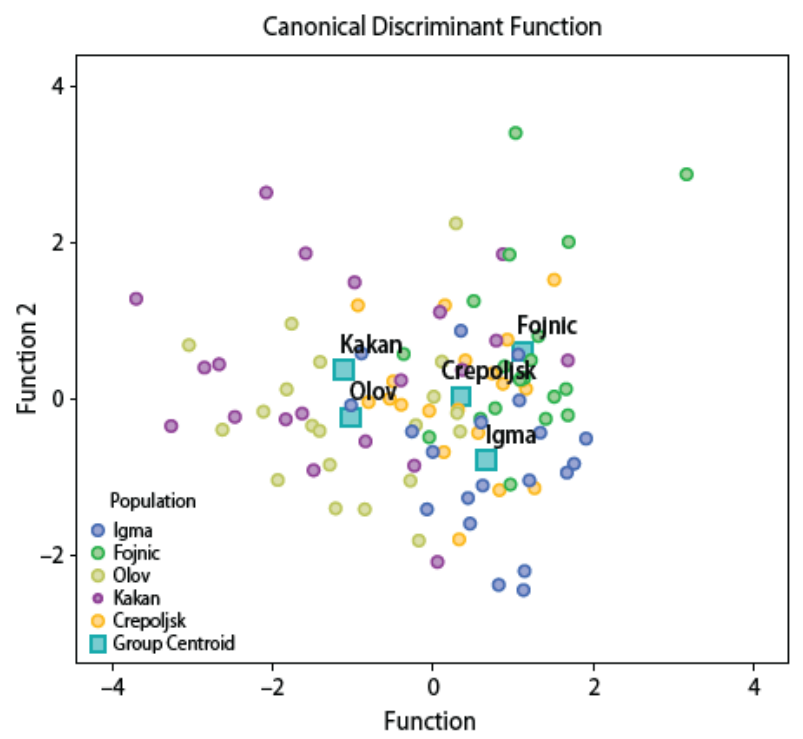

Fig. 2. Discriminant analysis of groups 
separations into two different groups for the function 1: Kakanj and Olovo populations fell into one group and other populations into another, but this was not sufficient to obtain significant differences. The reason should be sought in the great variability obtained during the study, by comparison with the research in which morphological characteristics of cones, seeds and skin were analyzed (Ballian and Čabravdić 2005), which yielded three completely different groups differing from those in the current study.

\section{Cluster analysis}

The results of discriminant analysis, were assumed as potential differentiation by the function 1 and suggested that a cluster analysis can be performed. The results confirmed that there were indeed two main groups, as indicated by the results of discriminant analysis. One group consisted of the Kakanj and Olovo populations, and the other of the Igman, Fojnica and Crepoljsko populations, as shown in tab. 5 and 6.

\section{Correlational connections of the researched traits}

Correlation analysis was conducted for all the dendrometrical findings and the seeds, germination and absolute germination characteristics of healthy seeds as well as those of rotten and barren seeds. Germination energy analysis yielded a striking correlational between absolute weight and absolute germination of healthy, rotten and barren seeds at a level $1 \%$. The presence of a negative correlation is of particular interest in relation to healthy ungerminated seeds and barren seeds (tab. 7).

The correlation between absolute germination and the parameters analyzed showed connections between the height, absolute weight, germination energy and healthy ungerminated seeds and barren seeds, where the correlation was negative. Here, positive correlation is of interest in regard to tree height, revealing that higher germination corresponds to a greater tree height. This is divergent in case of the position of cones on the tree (always on tree top), and relatively poor pollen produced when compared with other conifers. Taller trees are more easily pollinated, and this reduces selfpollination or inbreeding, which have a negative impact on germination. In case of healthy ungerminated seeds, there was observed a negative striking correlation (the order $1 \%$ ), for germination energy, absolute germination and rotten seeds. There was also a negative correlation with regard to tree height and age, suggesting that as the height and age increase percentage of healthy ungerminated seeds declines.

Correlations between rotten seeds and dendrometrical as well as physiological tree attributes analyzed were statistically interesting, being of the order $5 \%$ in relation to the presence of mistletoe on the trees. There was also a negative correlation observed with regard to

Tab. 5. Displaying frequency and grouping of descriptive indicators

\begin{tabular}{|c|c|c|c|c|c|c|c|c|c|c|c|}
\hline & \multicolumn{2}{|c|}{$\begin{array}{c}\text { Germination } \\
\text { energy }\end{array}$} & \multicolumn{2}{|c|}{$\begin{array}{l}\text { Absolute } \\
\text { germination }\end{array}$} & \multicolumn{2}{|c|}{$\begin{array}{c}\text { Healthy } \\
\text { ungerminated seeds }\end{array}$} & \multicolumn{2}{|c|}{ Rotten seeds } & \multicolumn{2}{|c|}{ Empty seeds } \\
\hline & & Mean & $\begin{array}{l}\text { Std. } \\
\text { Dev. }\end{array}$ & Mean & $\begin{array}{l}\text { Std. } \\
\text { Dev. }\end{array}$ & Mean & Std. Dev. & Mean & $\begin{array}{l}\text { Std. } \\
\text { Dev. }\end{array}$ & Mean & $\begin{array}{l}\text { Std. } \\
\text { Dev. }\end{array}$ \\
\hline \multirow{3}{*}{ Cluster } & 1 & 3.22 & 1.90 & 18.32 & 7.78 & 38.68 & 9.76 & 2.91 & 2.58 & 40.31 & 9.30 \\
\hline & 2 & 8.46 & 7.71 & 34.56 & 12.43 & 29.32 & 11.65 & 4.76 & 3.62 & 31.33 & 8.90 \\
\hline & Combined & 5.32 & 5.67 & 24.82 & 12.68 & 34.94 & 11.46 & 3.65 & 3.16 & 36.72 & 10.11 \\
\hline
\end{tabular}

Tab. 6. Displaying frequency and grouping of populations

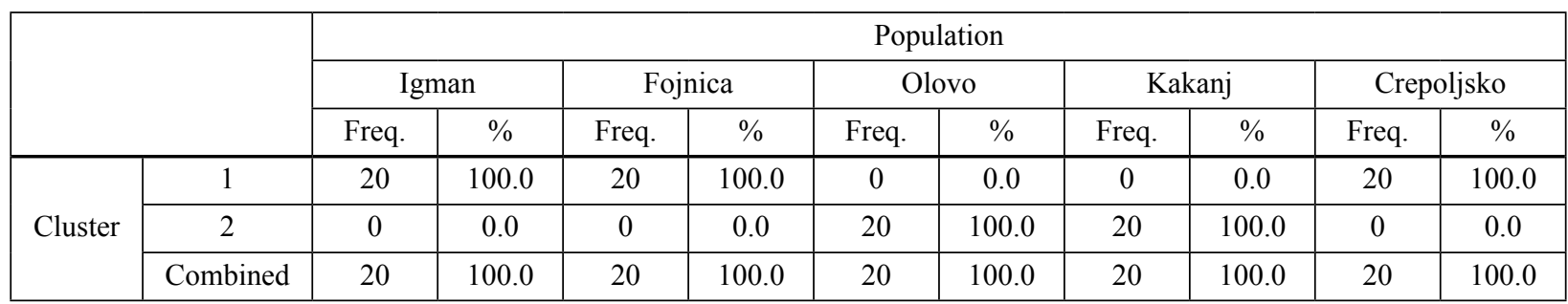


Tab. 7. Correlations between studied parameters

\begin{tabular}{|l|c|c|c|c|c|c|c|c|c|}
\hline Correlation & Height & DBH & Age & $\begin{array}{c}\text { Presence of } \\
\text { mistletoe }\end{array}$ & $\begin{array}{c}\text { Weight of } \\
1000 \text { seeds }\end{array}$ & $\begin{array}{c}\text { Absolute } \\
\text { germination }\end{array}$ & $\begin{array}{c}\text { Healthy unger- } \\
\text { minated seeds }\end{array}$ & $\begin{array}{c}\text { Rotten seeds } \\
\text { seeds }\end{array}$ \\
\hline $\begin{array}{l}\text { Germination } \\
\text { energy }\end{array}$ & 0.157 & 0.110 & -0.013 & -0.024 & $0.337^{* *}$ & $0.703^{* *}$ & $-0.476^{* *}$ & 0.163 \\
\hline Correlation & Height & BHD & Age & $\begin{array}{c}\text { Presence of } \\
\text { mistletoe }\end{array}$ & $\begin{array}{c}\text { Weight of } \\
1000 \text { seeds }\end{array}$ & $\begin{array}{c}\text { Germination } \\
\text { energy }\end{array}$ & $\begin{array}{c}\text { Healthy unger- } \\
\text { minated seeds }\end{array}$ & $\begin{array}{c}\text { Rotten seeds } \\
\text { seeds }\end{array}$ \\
\hline $\begin{array}{l}\text { Absolute } \\
\text { germination }\end{array}$ & $0.268^{* *}$ & 0.113 & 0.164 & 0.145 & $0.360^{* *}$ & $0.703^{* *}$ & $-0.667^{* *}$ & 0.191 & $-0.575^{* *}$ \\
\hline Correlation & Height & BHD & Age & $\begin{array}{c}\text { Presence of } \\
\text { mistletoe }\end{array}$ & $\begin{array}{c}\text { Weight of } \\
1000 \text { seeds }\end{array}$ & $\begin{array}{c}\text { Germination } \\
\text { energy }\end{array}$ & $\begin{array}{c}\text { Absolute } \\
\text { germination }\end{array}$ & Rotten seeds & $\begin{array}{c}\text { Empty } \\
\text { seeds }\end{array}$ \\
\hline $\begin{array}{l}\text { Healthy unger- } \\
\text { minated seed }\end{array}$ & $-0.318^{* *}$ & -0.163 & $-0.213^{*}$ & -0.110 & -0.174 & $-0.476^{* *}$ & $-0.667^{* *}$ & $-0.370^{* *}$ & -0.179 \\
\hline Correlation & Height & BHD & Age & $\begin{array}{c}\text { Presence of } \\
\text { mistletoe }\end{array}$ & $\begin{array}{c}\text { Weight of } \\
1000 \text { seeds }\end{array}$ & $\begin{array}{c}\text { Germination } \\
\text { energy }\end{array}$ & $\begin{array}{c}\text { Absolute } \\
\text { germination }\end{array}$ & $\begin{array}{c}\text { Healthy unger- } \\
\text { minated seeds }\end{array}$ & $\begin{array}{c}\text { Empty } \\
\text { seeds }\end{array}$ \\
\hline Rotten seed & 0.175 & 0.101 & 0.060 & $0.214^{*}$ & 0.153 & 0.163 & 0.191 & $-0.370^{* *}$ & -0.141 \\
\hline Correlation & Height & BHD & Age & $\begin{array}{c}\text { Presence of } \\
\text { mistletoe }\end{array}$ & $\begin{array}{c}\text { Weight of } \\
1000 \text { seeds }\end{array}$ & $\begin{array}{c}\text { Germination } \\
\text { energy }\end{array}$ & $\begin{array}{c}\text { Absolute } \\
\text { germination }\end{array}$ & $\begin{array}{c}\text { Healthy unger- } \\
\text { minated seeds }\end{array}$ & $\begin{array}{c}\text { Rotten } \\
\text { seeds }\end{array}$ \\
\hline Empty seed & -0.061 & -0.002 & -0.001 & -0.135 & $-0.319^{* *}$ & $-0.401^{* *}$ & $-0.575^{* *}$ & -0.179 & -0.141 \\
\hline
\end{tabular}

* Correlation is significant at 0.05 level.

** Correlation is significant at 0.01 level.

healthy ungerminated seeds. In case of barren seeds, a striking positive correlation of the order $1 \%$ for absolute seed weight, germination energy and absolute germination as opposed to expected negative correlation.

\section{Discussion}

No notable results were obtained with regard to the genetic overload of the populations studied by means of descriptive statistics, analysis of variance and discriminant or cluster analyses. The best results were shown by correlations between seed physiological characteristics and dendrometrical indicators.

Since silver fir grows in mixed and age-varied forests in Bosnia and Herzegovina, it is very difficult to come to a satisfactory decision, based on which sites should be selected for production of reproductive material. Another difficulty is that there are already existing solutions for central European forests which are very different ecologically from those of Bosnia, where silver fir is of superior quality. The present study attempts to resolve the above question by means of a wide-ranging physiological analysis of silver fir seeds from five populations, each divided into two subpopulations. The posi- tion of male and female flowers of silver fir is out of the ordinary, as they are located near the top of the tree. In addition, silver fir pollen is one of the largest, and consequently the heaviest, conifer pollens, and this places certain restrictions on pollination. As a rule, cross-pollination occurs between neighbouring trees, and these features are also associated with self-pollination and inbreeding, resulting in the production of sterile seeds and generating genetic drift or genetic isolation of the population (Hadžiselimović 2005), often purely reproductive in nature. The presence of healthy ungerminated seeds is associated with the specific physiological processes of maturing in favourable conditions, which can be overcome by simulation of germination by wetcold pre-treatment.

We deduce from the results of correlation dependencies that germination energy is markedly related to the absolute weight and germination of healthy ungerminated seeds and barren seeds, which is to be expected, as healthy heavy seeds germinate most rapidly. The speed of germination diminishes with percentage of ungerminated seeds in the sample, either rotten or sterile. Absolute germination acts in the same manner, and it should be noted that this is often associated with mechanical damage to the seed. When turpentine 
damage occurs, the seed is unable to germinate. It is also of interest that there is a strong positive correlation between tree height and absolute germination (germination increases with tree height). This is at variance with the position of flowers and cones on trees. Taller trees are better able to exchange pollen with other trees and other populations, reducing self-pollination and inbreeding, which results in far greater genetic vitality, as evidenced by a higher proportion of germinating seeds. The analysis of healthy ungerminated seeds yielded a negative correlation of the order $1 \%$ for germination energy, absolute germination and rotten seeds. Of particular interest is a negative correlation with tree age and height, suggesting that an increase in the height and age reduces percentage of healthy ungerminated seeds. The explanation as regards the height is that taller trees are better able to exchange genetic material, and the height is also related to age. It would be interesting to obtain further results relating to the aging process and how it affects the increase of the number of healthy ungerminated seeds, but we were unable to explain this within the scope of this study.

One of appealing results obtained concerned positive correlation between rotten seeds and the presence of mistletoe at statistically significant level $5 \%$. This can also be attributed to the loss of nutrients in seeds as a result of taking nutrients from the tree by mistletoe. This can prevent seeds from developing fully and they begin to rot during the germination stage. Mistletoe is one of the most significant parasites affecting the silver fir, (Uščuplić et al. 2007). It reduces seed quality, and thus should be strictly monitored in regard to silver fir natural regeneration. Further research should be undertaken on silver fir seeds and mistletoe impact. It is also interesting that there is a negative correlation between rotten and healthy ungerminated seeds. Therefore, genetic barriers which led to ungermination of healthy seeds should be more researched.

As the silver fir is of great importance and economic value in Bosnia and Herzegovina, it should be considered as subject of further long-term attention. The results of the present study can be of great value by adding an important part to silvicultural activities related to silver fir propagation and the selection of individuals or sites for the production of reproductive material. Further care should be also taken over actual extraction of seed characteristics, ensuring that above-average sam- ples are selected from as many individual tall silver fir trees as possible and avoiding less tall, single-generation, single-level stands so as to assure seed quality.

\section{Conclusions}

All the characteristics studied, such as absolute seed weight, germination energy and absolute germination are within the ranges of previous studies.

Physiological characteristics of silver fir seeds studied in the populations of Bosnia and Herzegovina revealed significant interpopulation variability compared with the variability between subpopulations. The inclusion of tree characteristics (height, BHD, age and the presence of mistletoe) proved to be justified in achieving new quality of research. Tree height had a positive effect on seed quality - or rather on absolute germination, which increased with tree height. Accordingly, seeds should be collected only from the trees of above average height. The share of healthy ungerminated seeds decreases proportionally to tree height, so these should be henceforth collected from silver fir trees of above average height.

The effect of mistletoe is also of interest, as its presence increases percentage of rotten seeds with consequential loss of quality. Further research should be conducted in this regard.

\section{References}

Ballian D. 2000. Intra-population and inter-population variability of some morphological and physiological characteristics of the silver fir (Abies alba Mill.) in one part of the natural range in Bosnia and Herzegovina. Annales forestales, 24 (1), 1-23.

Ballian D., Čabaravdić A. 2005. Međupopulacijska varijabilnost nekih morfoloških svojstava obične jele (Abies alba Mill.) iz središnje Bosne. Rad. Šumar. Inst. Jastrebarsko, 40 (1), 5-18.

Čabrajić T. 1960. Analiza šišarica i sjemena jele i smrče. Šumarstvo, 3-4.

Đikić S., Jovanćević M., Panov A. 1965. Principi i perspektive unapređenja proizvodnje šumskog sjemena u Bosni i Hercegovini. Šumarski fakultet Sarajevo, Posebna izdanja. 
Fukarek P. 1970. Rasprostranjenje i raprostranjenosti bukve, jele i smrče na području Bosne i Hercegovine, Akad. nauka i umjetnosti BiH, 39 (11), 231-256.

Gagov V. 1973. Izmenčivost pri semenata ot obliknovenata ela ot različni populacii $\mathrm{v}$ NR Bulgarija. Naučni trudovi na VLTI, Sofija, Tom 19, 51-56.

Gajić M. 1962. Još jedno saopštenje u vezi sa bojom semena jele (Abies alba Mill.). Šumarstvo, 1/ 2, $75-76$.

Gradečki-Poštenjak M. 2002. Varijabilnost nekih svojstava češera i sjemena obične jele (Abies alba Mill.) u dijelu prirodnog rasprostranjenja u Hrvatskoj, Šumarski fakultet Sveučilišta u Zagrebu, Magistarski rad, Zagreb.

Gradi A. 1973. New techniques and progress in processes of extraction of forest seeds. Internat. Symp. on Seed Processing. Bergen, 1 (7), 1-14.

Hadžiselimović R. 2005. Bioantropologija - Biodiverzitet recentnog čovjeka. INGEB, Sarajevo.

Kantor J. 1967. Pispevěk ke studiu některych děděných vlastností jedle bílé (Abies alba Mill.). Lesnícky časopis, 13 (4), 309-318.

Lafférs A. 1970. Hodnotenie semenášikov jedle proveniencií zo Slovenska. Vedecke prace VULH, 12, 25-62.

Lafférs A. 1979. Evaluation of seed weight in fir of Czechoslovakian and foreign provenance in rela- tion to modified geographical latitude, to geographical longitude and to particular mountain ranges of Europe. Lesnicky časopis, 25, 111-125.

Machaniček J. 1967. Stanoveni životnosti jedlovich semen. Prace VULHM, 34.

Matić V., Drinić P., Stefanović V., Čirić M. 1971. Stanje šuma u SR Bosni i Hercegovini, prema inventuri na velikim površinama u 1964-1968 godini. Šum. fak. i inst. za šum. posebna izdanja, 7.

Popnikola N. 1979. Morfološke karakteristike i varijabilnost sjemena jele (Abies alba Mill.) u prirodnim populacijama SR Makedonije. Šumarstvo, 2/3, 39-55.

Rohmeder E. 1960. Bastardierung der Gattung Abies. Silvae Genetica, 9 (5), 136-137.

Tikvić I., Seletković Z., Anić I. 1995. Propadanje šuma kao pokazatelj promjene ekoloških uvjeta u atmosferi. Šum. List, 11/12, 361-371.

Uščuplić M. 1992. Uticaj sistema gazdovanja na pojavu imele (Viscum album L.). Glasnik šumarskog fakulteta, 7-18.

Uščuplić M., Dautbašić M., Treštić T., Selman E., Mujezinović O., Nišić T., Jokanović B. 2007. Bolesti i štetnici obične jele (Abies alba Mill.) u Bosni i Hercegovini. Društvo za zaštitu bilja u BiH, Sarajevo.

Vanin A.I. 1960. Dendrologija, Moskva. 